\title{
Some Trace Element Contents and Ratios in Prostatic Fluid as Ancillary Diagnostic Tools in Distinguishing Between the Benign Prostatic Hyperplasia and Prostate Cancer
}

\author{
Vladimir Zaichick ${ }^{1 *}$ and Sofia Zaichick ${ }^{2}$ \\ ${ }^{1}$ Radionuclide Diagnostics Department, Medical Radiological Research Centre, Russia \\ ${ }^{2}$ Laboratory of Dr. Gabriela Caraveo Piso, Feinberg School of Medicine, Northwestern University, USA
}

Submission: May 30, 2019; Published: June 10, 2019

"Correspondence Author: Prof. Dr. Vladimir Zaichick, Radionuclide Diagnostics Department, Medical Radiological Research Centre, Korolyev St. 4, Obninsk 249036, Kaluga region, Russia

\section{Abstract}

Prostate cancer $(\mathrm{PCa})$ and benign prostatic hyperplasia $(\mathrm{BPH})$ is an internationally important health problem of the man. The association between PCa and BPH is significant. As a result of this, BPH may be misdiagnosed as a malignant condition. This warrants the need of reliable diagnostic tool which has ability to differentiate BPH from the PCa. The aim of this exploratory study was to evaluate whether significant difference in the contents of $\mathrm{Zn}$ and some other trace elements as well as in the $\mathrm{Zn} /$ trace elements ratios of prostatic fluid exist between the hyperplastic and malignantly transformed prostate. Prostatic fluid levels of $\mathrm{Br}$, Fe, $\mathrm{Rb}, \mathrm{Sr}$, and $\mathrm{Zn}$ were prospectively evaluated and $\mathrm{Zn} / \mathrm{Br}, \mathrm{Zn} / \mathrm{Fe}, \mathrm{Zn} / \mathrm{Rb}$, and $\mathrm{Zn} / \mathrm{Sr}$ ratios were calculated in 52 patients with BPH and 24 patients with PCa. Measurements were performed using energy dispersive X-ray fluorescent microanalysis. It was found that in the prostatic fluid samples of PCa group the levels of $\mathrm{Rb}, \mathrm{Zn}, \mathrm{Zn} / \mathrm{Br}, \mathrm{Zn} / \mathrm{Fe}$, and $\mathrm{Zn} / \mathrm{Sr}$ are 3.2, 7.7, 23.8, 30.3, and 16.1 times, respectively, lower than levels of these parameters of patients with BPH. It was supposed that the changes of Rb, $\mathrm{Zn}$, $\mathrm{Zn} / \mathrm{Br}, \mathrm{Zn} / \mathrm{Fe}$, and $\mathrm{Zn} / \mathrm{Sr}$ levels in the prostatic fluid samples can be used as tumor markers in distinguishing between BPH and PCa.

Keywords: Prostate cancer; Benign prostatic hyperplasia; Prostatic fluid; Trace element contents; Trace element ratios; Energy-dispersive X-ray fluorescent analysis

Abbreviations: BPH: Benign Prostatic Hyperplasia; CRM: Certified Reference Materials; EDXRF: Energy Dispersive X-ray Fluorescence; EPF: Expressed Prostatic Fluid; IAEA: International Atomic Energy Agency; MR: Magnetic Resonance; Pca: Prostate Cancer; PSA: Prostate Specific Antigen; TE: Trace Elements; TRUS: Trance Rectal Ultra Sonography

\section{Introduction}

In industrialized countries prostate cancer $(\mathrm{PCa})$ is one of the most common malignant diseases in men. PCa incidence and mortality rates are among the highest for North America, Oceania, and Northern and Western Europe [1,2]. The American Cancer Society declares PCa as the most common cancer in males and the second leading cause of cancer death [3]. Moreover, PCa is the leading cancer in terms of incidence and mortality in men from Africa and the Caribbean [1]. PCa in China has also become a major public health concern [4].

Benign prostatic hyperplasia (BPH) is a benign tumor that develops in men and represents the most common urologic disease among them after the age of fifty $[5,6]$. BPH is histologically defined as an overgrowth of the epithelial and stromal cells from the transition zone and periurethral area of prostate [7]. The excessive cell proliferation associated with BPH causes benign prostatic enlargement, bladder outlet obstruction, and lower urinary tract symptoms, which afflict the patients. Prostate enlargement infects almost all men as they get older. Incidence of histological BPH could be over $70 \%$ at 60 years old and over $90 \%$ at 70 years old $[5,8]$.

To date, we still have no precise knowledge of the biochemical, cellular and molecular processes underlying the pathogenesis of BPH. Although the influence of androgens and estrogens has been demonstrated, hormonal factors alone may not fully explain BPH development $[9,10]$. Thus, the both PCa and $\mathrm{BPH}$ is the very common urologic disease in adult males. Moreover, use systematic review methods provide the statistical evidence that the association between PCa and BPH is significant $[11,12]$. BPH can be a cause of an elevated prostate specific antigen (PSA) level in blood [13]. In these cases, it is difficult 


\section{Cancer Therapy \& Oncology International Journal}

to differentiate BPH from PCa because the findings of imaging modalities like TRUS and conventional MR Imaging can mimic those of PCa. Even biopsy doesn't play promising role in the diagnosis of BPH. As a result of this, BPH may be misdiagnosed as a malignant condition and end up in aggressive surgical management resulting in increased morbidity. This warrants the need of reliable diagnostic tool which has ability not only to diagnose BPH reliably but also to differentiate it from the PCa.

It was reported that the risk of having $\mathrm{PCa}$ and $\mathrm{BPH}$ depends on lifestyle and diet, including the intake of zinc (Zn) and some other trace elements (TE) [14-18]. TE have essential physiological functions such as maintenance and regulation of cell function, gene regulation, activation or inhibition of enzymatic reactions, and regulation of membrane function. Essential or toxic (mutagenic, carcinogenic) properties of TE depend on tissue-specific need or tolerance, respectively [19]. Excessive accumulation or a deficit of the TE may disturb the cell functions and may result in cellular degeneration or death [19-23]. Besides only total amounts, ratios of TE, which reflect relationships between them, should be taken into account on a regular basis to allow for a more reliable description of the individual TE and health status [19,24].

In our previous studies a significant involvement of $\mathrm{Zn}$ and some other TE in the function of prostate was observed [2539]. Moreover, it was found that intracellular $\mathrm{Zn}$ and calcium (Ca) excess is one of the main factors in the etiology of prostate cancer $[16-18,24,25]$. One of the main functions of prostate gland is a production of prostatic fluid [40] with extremely high concentration of $\mathrm{Zn}$ and some other chemical elements. The first finding of remarkable high level of $\mathrm{Zn}$ concentration in human expressed prostatic fluid (EPF) was reported in the beginning of 1960s [41]. Analyzing EPF expressed from prostate of 8 apparently healthy men aged 25-55 years it was found that $\mathrm{Zn}$ concentration varied in range from 300 to $730 \mathrm{mg} / \mathrm{L}$. After this finding several investigators have suggested that the measurement of Zn level in EPF may be useful as a marker of prostate secretory function $[42,43]$. It promoted a more detailed study of Zn concentration in EPF of healthy subjects and in those with different prostate diseases, including PCa $[43,44]$. A detailed review of these studies, reflecting the contradictions within accumulated data, was given in our earlier publication [44].

In present study it was supposed by us that apart from Zn the levels of some other TE and ratios Zn/TE contents in EPF have to reflect a difference between possible functional suppression of hyperplastic prostate and functional disintegration of cancerous prostate. Thus, this work had four aims. The first aim was to assess the $\mathrm{Br}, \mathrm{Fe}, \mathrm{Rb}, \mathrm{Sr}$, and $\mathrm{Zn}$ concentration in the EPF samples obtained from patients with BPH and PCa using 109Cd EDXRF micro-method. The second aim was to calculate $\mathrm{Zn} / \mathrm{Br}, \mathrm{Zn} / \mathrm{Fe}$, $\mathrm{Zn} / \mathrm{Rb}, \mathrm{Zn} / \mathrm{Sr}$ ratios in all EPF samples. The third aim was to evaluate the quality of obtained results and to compare obtained results with published data. The last aim was to compare the concentration of $\mathrm{Br}, \mathrm{Fe}, \mathrm{Rb}, \mathrm{Sr}$, and $\mathrm{Zn}$ as well as $\mathrm{Zn} / \mathrm{Br}, \mathrm{Zn} / \mathrm{Fe}, \mathrm{Zn} /$ $\mathrm{Rb}, \mathrm{Zn} / \mathrm{Sr}$ ratios in EPF samples of hyperplastic and cancerous prostate gland.

All studies were approved by the Ethical Committees of the Medical Radiological Research Centre, Obninsk. All procedures performed in studies involving human participants were in accordance with the ethical standards of the institutional and/ or national research committee and with the 1964 Helsinki declaration and its later amendments or comparable ethical standards.

\section{Materials and Methods}

Specimens of EPF were obtained from 52 patients with $\mathrm{BPH}$ (mean age 63 \pm 6 years, range 52-75 years) and from 24 patients with PCa (mean age $65 \pm 10$ years, range $47-77$ years) by qualified urologists in the Urological Department of the Medical Radiological Research Centre using standard rectal massage procedure. In all cases the diagnosis of BPH or PCa has been confirmed by clinical examination, including morphological results obtained during studies of biopsy and resected materials. Patients with BPH combined with chronic prostatitis or prostatic stones were excluded from the study. Subjects were asked to abstain from sexual intercourse for 3 days preceding the procedure. Specimens of EPF were obtained in sterile containers which were appropriately labeled. Twice twenty $\mu \mathrm{L}$ (microliters) of fluid were taken by micropipette from every specimen for TE measurement, while the rest of the fluid was used for cytological and bacteriological investigations to exclude prostatitis. The chosen $20 \mu \mathrm{L}$ of the EPF was dropped on $11.3 \mathrm{~mm}$ diameter disk made of thin, ash-free filter papers fixed on the Scotch tape pieces and dried in an exsiccator at room temperature. Then the dried sample was covered with $4 \mu \mathrm{m}$ Dacron film and centrally pulled onto a Plexiglas cylindrical frame.

To determine concentration of the TE by comparison with a known standard, aliquots of solutions of commercial, chemically pure compounds were used for a device calibration [45]. The standard samples for calibration were prepared in the same way as the samples of prostate fluid. Because there were no available liquid Certified Reference Material (CRM) ten subsamples of the powdery CRM produced by the International Atomic Energy Agency (IAEA) - CRM IAEA H-4 (animal muscle) were analyzed to estimate the precision and accuracy of results. Every CRM sub-sample weighing about $3 \mathrm{mg}$ was applied to the piece of Scotch tape serving as an adhesive fixing backing. An acrylic stencil made in the form of a thin-walled cylinder with $11.3 \mathrm{~mm}$ inner diameter was used to apply the sub-sample to the Scotch tape. The polished-end acrylic pestle which is a constituent of the stencil set was used for uniform distribution of the sub-sample within the Scorch surface restricted by stencil inner diameter. When the sub-sample was slightly pressed to the Scotch adhesive sample, the stencil was removed. Then 


\section{Cancer Therapy \& Oncology International Journal}

the sub-sample was covered with 4 am Dacron film. Before the sample was applied, pieces of Scotch tape and Dacron film were weighed using analytical balance. Those were again weighed together with the sample inside to determine the sub-sample mass precisely.

The facility for radionuclide-induced energy dispersive X-ray fluorescence included an annular 109Cd source with an activity of $2.56 \mathrm{GBq}$, Si (Li) detector with electric cooler and portable multi-channel analyzer combined with a PC. Its resolution was $270 \mathrm{eV}$ at the $6.4 \mathrm{keV}$ line. The facility functioned as follows. Photons with the $22.1 \mathrm{keV}$ energy from $109 \mathrm{Cd}$ source are sent to the surface of a specimen analyzed, where they excite the characteristic fluorescence radiation, inducing the K $\alpha$ X-rays of trace elements. The fluorescence radiation got to the detector through a $10 \mathrm{~mm}$ diameter collimator to be recorded. The duration of the $\mathrm{Zn}$ concentration measurement was $10 \mathrm{~min}$. The duration of the $\mathrm{Zn}$ concentration measurement together with $\mathrm{Br}, \mathrm{Fe}, \mathrm{Rb}$, and $\mathrm{Sr}$ was $60 \mathrm{~min}$. The intensity of $\mathrm{K \alpha}$-line of $\mathrm{Br}, \mathrm{Fe}, \mathrm{Rb}, \mathrm{Sr}$, and Zn for EPF samples and standards was estimated on calculation basis of the total area of the corresponding photopeak in the spectra. All EPF samples for EDXRF were prepared in duplicate and mean values of TE contents were used in final calculation. Using the Microsoft Office Excel programs, the summary of statistics, arithmetic mean, standard deviation, standard error of mean, minimum and maximum values, median, percentiles with 0.025 and 0.975 levels was calculated for TE concentrations and $\mathrm{Zn} / \mathrm{TE}$ ratios in EPF of hyperplastic and cancerous prostate. The difference in the results between two groups of samples (BPH and PCa) was evaluated by the parametric Student's t-test and non-parametric Wilcoxon-Mann-Whitney U-test.

\section{Results}

Table 1: EDXRF data of $\mathrm{Br}, \mathrm{Fe}, \mathrm{Rb}, \mathrm{Sr}$, and $\mathrm{Zn}$ contents in the IAEA H-4 (animal muscle) reference material compared to certified values (mg/ $\mathrm{kg}$, dry mass basis).

\begin{tabular}{|c|c|c|c|c|}
\hline \multirow[t]{2}{*}{ Element } & \multicolumn{3}{|c|}{ Certified values } & \multirow{2}{*}{$\begin{array}{c}\text { This work Results } \\
\text { Mean } \pm \text { SD }\end{array}$} \\
\hline & Mean & 95\% Confidence Interval & Type & \\
\hline $\mathrm{Br}$ & 4.1 & $3.5-4.7$ & $\mathrm{C}$ & $5.0 \pm 1.2$ \\
\hline $\mathrm{Fe}$ & 49 & $47-51$ & $\mathrm{C}$ & $48 \pm 9$ \\
\hline $\mathrm{Rb}$ & 18 & $17-20$ & $\mathrm{C}$ & $22 \pm 4$ \\
\hline $\mathrm{Sr}$ & 0.1 & - & $\mathrm{N}$ & $<1$ \\
\hline $\mathrm{Zn}$ & 86 & $83-90$ & $\mathrm{C}$ & $90 \pm 5$ \\
\hline
\end{tabular}

Mean: Arithmetical Mean, SD: Standard Deviation, C: Certified Values, N: Non-Certified values

Table 1 depicts our data for $\mathrm{Br}, \mathrm{Fe}, \mathrm{Rb}, \mathrm{Sr}$, and $\mathrm{Zn}$ mass fractions in ten sub-samples of CRM IAEA H-4 (animal muscle) and the certified values of this reference material. Of $4(\mathrm{Br}, \mathrm{Fe}, \mathrm{Rb}$, and $\mathrm{Zn}$ ) TE with certified values for the CRM IAEA H-4 (animal muscle) we determined contents of all certified elements (Table 1). Mean values (MUSD) for $\mathrm{Br}, \mathrm{Fe}, \mathrm{Rb}$, and $\mathrm{Zn}$ were in the range of $95 \%$ confidence interval. Good agreement of the TE contents analyzed by $109 \mathrm{Cd}$ radionuclide-induced EDXRF with the certified data of CRM IAEA H-4 (Table 1) indicate an acceptable accuracy of the results obtained in the study of the prostatic fluid presented in Tables 2-4.

Table 2: Some basic statistical parameters of $\mathrm{Br}$, $\mathrm{Fe}, \mathrm{Rb}, \mathrm{Sr}$, and $\mathrm{Zn}$ concentration (mg/L) and also $\mathrm{Zn} / \mathrm{Br}$, $\mathrm{Zn} / \mathrm{Fe}, \mathrm{Zn} / \mathrm{Rb}$, and $\mathrm{Zn} / \mathrm{Sr}$ concentration ratio in prostate fluid of patients with $\mathrm{BPH}$ and $\mathrm{PCa}$.

\begin{tabular}{|c|c|c|c|c|c|c|c|c|c|}
\hline Condition of prostate & Element or ratio & Mean & SD & SEM & Min & Max & Median & Per. 0.025 & Per. 0.975 \\
\hline $\mathrm{BPH}$ & $\mathrm{Br}$ & 2.32 & 1.84 & 0.30 & 0.230 & 8.70 & 1.62 & 0.268 & 5.84 \\
\hline $52-75$ years & $\mathrm{Fe}$ & 11.5 & 10.8 & 1.8 & 1.06 & 54.1 & 9.31 & 1.09 & 38.9 \\
\hline $\mathrm{n}=52$ & $\mathrm{Rb}$ & 1.70 & 1.41 & 0.23 & 0.210 & 5.04 & 1.46 & 0.254 & 5.04 \\
\hline & $\mathrm{Sr}$ & 1.41 & 1.09 & 0.26 & 0.230 & 4.79 & 1.12 & 0.300 & 4.02 \\
\hline & $\mathrm{Zn}$ & 488 & 302 & 42 & 45.0 & 977 & 427 & 81.4 & 962 \\
\hline & $\mathrm{Zn} / \mathrm{Br}$ & 437 & 545 & 88 & 10.5 & 2416 & 219 & 27.1 & 1874 \\
\hline & $\mathrm{Zn} / \mathrm{Fe}$ & 92 & 117 & 19 & 2.81 & 508 & 43.2 & 5.93 & 374 \\
\hline $\mathrm{Zn} / \mathrm{Rb}$ & 471 & 459 & 74 & 49.0 & 1809 & 283 & 51.8 & 1793 \\
\hline $\mathrm{Zn} / \mathrm{Sr}$ & 596 & 787 & 191 & 71.0 & 3361 & 277 & 74.8 & 2434 \\
\hline $\mathrm{BCa}$ & $\mathrm{Br}$ & 4.51 & 7.19 & 2.27 & 0.697 & 24.3 & 2.08 & 0.704 & 20.4 \\
\hline $\mathrm{Fe}$ & 21.7 & 28.8 & 8.7 & 7.70 & 107 & 13.9 & 7.70 & 86.8 \\
\hline $\mathrm{n}=24$ & $\mathrm{Rb}$ & 0.53 & 0.38 & 0.11 & 0.013 & 1.39 & 0.422 & 0.024 & 1.26 \\
\hline & $\mathrm{Sr}$ & 1.70 & 2.15 & 0.76 & 0.230 & 6.83 & 0.872 & 0.275 & 5.95 \\
\hline
\end{tabular}




\section{Cancer Therapy \& Oncology International Journal}

\begin{tabular}{|c|c|c|c|c|c|c|c|c|c|}
\hline & $\mathrm{Zn} / \mathrm{Br}$ & 18.5 & 25.7 & 8.1 & 0.389 & 68.3 & 6.86 & 0.685 & 67.0 \\
\hline & $\mathrm{Zn} / \mathrm{Fe}$ & 2.99 & 4.37 & 1.32 & 0.237 & 13.0 & 0.766 & 0.239 & 12.3 \\
\hline & $\mathrm{Zn} / \mathrm{Rb}$ & 900 & 2540 & 733 & 6.77 & 8840 & 23.8 & 6.86 & 6844 \\
\hline & $\mathrm{Zn} / \mathrm{Sr}$ & 36.8 & 54.9 & 19.2 & 2.20 & 163 & 16.8 & 2.21 & 146 \\
\hline
\end{tabular}

M: Arithmetic Mean, SD: Standard Deviation; SEM: Standard error of Mean, Min: Minimum value, Max: maximum value, Per. 0.025: percentile with 0.025 level, Per. 0.975: Percentile with 0.975 level, DL: Detection Limit.

Table 3: Median, minimum and maximum value of means of $\mathrm{Br}, \mathrm{Fe}, \mathrm{Rb}, \mathrm{Sr}$, and $\mathrm{Zn}$ concentration (mg/L) and $\mathrm{Zn} / \mathrm{Br}$, $\mathrm{Zn} / \mathrm{Fe}, \mathrm{Zn} / \mathrm{Rb}$, and $\mathrm{Zn} / \mathrm{Sr}$ concentration ratio in prostate fluid of patients with $\mathrm{BPH}$ and $\mathrm{PCa}$ according to data from the literature

\begin{tabular}{|c|c|c|c|c|c|}
\hline \multirow{2}{*}{$\begin{array}{l}\text { Condition of } \\
\text { Prostate }\end{array}$} & \multirow{2}{*}{$\begin{array}{l}\text { Element or } \\
\quad \text { Ratio }\end{array}$} & \multicolumn{3}{|c|}{ Published data [Reference] } & \multirow{2}{*}{$\begin{array}{c}\text { This work results } \\
\mathrm{M} \pm \mathrm{SD}\end{array}$} \\
\hline & & $\begin{array}{l}\text { Median of } \\
\text { means (n)* }\end{array}$ & $\begin{array}{l}\text { Minimum of means } M \text { or } \\
M \pm S D,(n)^{* *}\end{array}$ & Maximum of means $M \pm S D,(n)^{* *}$ & \\
\hline \multirow[t]{9}{*}{$\mathrm{BPH}$} & $\mathrm{Br}$ & - & - & - & $2.32 \pm 1.84$ \\
\hline & $\mathrm{Fe}$ & - & - & - & $11.5 \pm 10.8$ \\
\hline & $\mathrm{Rb}$ & $2.35(1)$ & $2.35 \pm 1.85(11)[43]$ & $2.35 \pm 1.85(11)[43]$ & $1.70 \pm 1.41$ \\
\hline & $\mathrm{Sr}$ & - & - & - & $1.41 \pm 1.09$ \\
\hline & $\mathrm{Zn}$ & $459(7)$ & $268(7)[46]$ & $9870 \pm 10130(11)[47]$ & $488 \pm 302$ \\
\hline & $\mathrm{Zn} / \mathrm{Br}$ & - & - & - & $437 \pm 545$ \\
\hline & $\mathrm{Zn} / \mathrm{Fe}$ & - & - & - & $92 \pm 117$ \\
\hline & $\mathrm{Zn} / \mathrm{Rb}$ & - & - & - & $471 \pm 459$ \\
\hline & $\mathrm{Zn} / \mathrm{Sr}$ & - & - & - & $596 \pm 787$ \\
\hline \multirow[t]{9}{*}{$\mathrm{PCa}$} & $\mathrm{Br}$ & - & - & - & $4.51 \pm 7.19$ \\
\hline & $\mathrm{Fe}$ & - & - & - & $21.7 \pm 28.8$ \\
\hline & $\mathrm{Rb}$ & $1.11(1)$ & $1.11 \pm 0.57(15)[43]$ & $.1 .11 \pm 0.57$ (15) [43] & $0.53 \pm 0.38$ \\
\hline & $\mathrm{Sr}$ & - & - & - & $1.70 \pm 2.15$ \\
\hline & $\mathrm{Zn}$ & $65.4(6)$ & $34.7 \pm 34.6(13)[48]$ & $722(3)$ [49] & $62.0 \pm 98.3$ \\
\hline & $\mathrm{Zn} / \mathrm{Br}$ & - & - & - & $18.5 \pm 25.7$ \\
\hline & $\mathrm{Zn} / \mathrm{Fe}$ & - & - & - & $2.99 \pm 4.37$ \\
\hline & $\mathrm{Zn} / \mathrm{Rb}$ & - & - & - & $900 \pm 2540$ \\
\hline & $\mathrm{Zn} / \mathrm{Sr}$ & - & - & - & $36.8 \pm 54.9$ \\
\hline
\end{tabular}

M: Arithmetic Mean, SD: Standard Deviation, $(n)^{*}$ : Number of all References, $(n)^{* *}$ : Number of Samples.

Table 4: Comparison of mean values $(\mathrm{M} \pm \mathrm{SEM}$ ) of $\mathrm{Br}$, Fe, $\mathrm{Rb}, \mathrm{Sr}$, and $\mathrm{Zn}$ concentration (mg/L) and also $\mathrm{Zn} / \mathrm{Br}, \mathrm{Zn} / \mathrm{Fe}, \mathrm{Zn} / \mathrm{Rb}$, and $\mathrm{Zn} / \mathrm{Sr}$ concentration ratio in prostate fluid of patients with $\mathrm{BPH}$ and $\mathrm{PCa}$.

\begin{tabular}{|c|c|c|c|c|c|}
\hline \multirow{2}{*}{ Element or Ratio } & \multicolumn{4}{|c|}{ Age Groups } & Ratios \\
\cline { 2 - 6 } & $\mathbf{B P H}$ & PCa & Student's t-test $\mathbf{s} \leq$ & U-test* $\mathbf{p}$ & PCa to BPH \\
\hline $\mathrm{Br}$ & $2.32 \pm 0.30$ & $4.51 \pm 2.27$ & 0.364 & $>0.05$ & 1.94 \\
\hline $\mathrm{Fe}$ & $11.5 \pm 1.8$ & $21.7 \pm 8.7$ & 0.272 & $>0.05$ & 1.89 \\
\hline $\mathrm{Rb}$ & $1.70 \pm 0.23$ & $0.53 \pm 0.11$ & $\mathbf{0 . 0 0 0 0 2 4}$ & $<\mathbf{0 . 0 1}$ & 0.31 \\
\hline $\mathrm{Sr}$ & $1.41 \pm 0.26$ & $1.70 \pm 0.76$ & 0.729 & $>0.05$ & 1.21 \\
\hline $\mathrm{Zn}$ & $488 \pm 42$ & $62.0 \pm 20.1$ & $\mathbf{0 . 0 0 0 0 0 0 0 1}$ & $<\mathbf{0 . 0 1}$ & 0.13 \\
\hline $\mathrm{Zn} / \mathrm{Br}$ & $437 \pm 88$ & $18.5 \pm 8.1$ & $\mathbf{0 . 0 0 0 0 3 3}$ & $<\mathbf{0 . 0 1}$ & 0.042 \\
\hline $\mathrm{Zn} / \mathrm{Fe}$ & $92 \pm 19$ & $2.99 \pm 1.32$ & $\mathbf{0 . 0 0 0 0 5 6}$ & $<\mathbf{0 . 0 1}$ & 0.033 \\
\hline $\mathrm{Zn} / \mathrm{Rb}$ & $471 \pm 74$ & $900 \pm 733$ & 0.572 & $>0.05$ & 1.91 \\
\hline $\mathrm{Zn} / \mathrm{Sr}$ & $596 \pm 191$ & $36.8 \pm 19.2$ & $\mathbf{0 . 0 1}$ & $<\mathbf{0 . 0 1}$ & 0.062 \\
\hline
\end{tabular}

M: Arithmetic Mean, SEM: Standard Error of Mean, ${ }^{*}$ Wilcoxon-Mann-Whitney U-test, bold: Significant difference $(p \leq 0.05)$.

Table 2 presents certain statistical parameters (arithmetic mean, standard deviation, standard error of mean, minimal and maximal values, median, percentiles with 0.025 and 0.975 levels) of the $\mathrm{Br}, \mathrm{Fe}, \mathrm{Rb}, \mathrm{Sr}$, and $\mathrm{Zn}$ concentrations as well as of the $\mathrm{Zn} / \mathrm{Br}, \mathrm{Zn} / \mathrm{Fe}, \mathrm{Zn} / \mathrm{Rb}, \mathrm{Zn} / \mathrm{Sr}$ ratios in EPF of patients with $\mathrm{BPH}$ and PCa. The comparison of our results with published data for 
$\mathrm{Br}, \mathrm{Fe}, \mathrm{Rb}, \mathrm{Sr}$, and $\mathrm{Zn}$ concentrations also for $\mathrm{Zn} / \mathrm{Br}, \mathrm{Zn} / \mathrm{Fe}, \mathrm{Zn} /$ $\mathrm{Rb}, \mathrm{Zn} / \mathrm{Sr}$ ratios in EPF of hyperplastic and cancerous prostate [41-44,46-50] is shown in Table 3. A number of values for $\mathrm{Zn}$ concentrations in EPF were not expressed on a wet mass basis in the cited literature. Therefore, we calculated these values using the published data for water $-93.2 \%$ [50]. The ratios of means and the differences between mean values of $\mathrm{Br}, \mathrm{Fe}, \mathrm{Rb}, \mathrm{Sr}$, and $\mathrm{Zn}$ concentrations as well as of the $\mathrm{Zn} / \mathrm{Br}, \mathrm{Zn} / \mathrm{Fe}, \mathrm{Zn} / \mathrm{Rb}, \mathrm{Zn} /$ $\mathrm{Sr}$ ratios in EPF of patients with BPH and PCa are presented in Table 4.

\section{Discussion}

The mean values and all selected statistical parameters were calculated for five $(\mathrm{Br}, \mathrm{Fe}, \mathrm{Rb}, \mathrm{Sr}$, and $\mathrm{Zn}) \mathrm{TE}$ concentrations and for four $\mathrm{Zn} / \mathrm{TE}$ ( $\mathrm{Zn} / \mathrm{Br}, \mathrm{Zn} / \mathrm{Fe}, \mathrm{Zn} / \mathrm{Rb}$, and $\mathrm{Zn} / \mathrm{Sr}$ ) ratios (Table 2). The concentrations of $\mathrm{Br}, \mathrm{Fe}, \mathrm{Rb}, \mathrm{Sr}$, and $\mathrm{Zn}$ were measured in all, or a major portion of EPF samples of hyperplastic and cancerous prostate. The mean of Zn concentration obtained for $\mathrm{BPH}$ group of prostate fluid, as shown in Table 3, agrees well with median of means cited by other researches [41-44,46-50]. The mean of $\mathrm{Rb}$ concentration obtained for EPF samples of CP group agrees well with our data reported 38 years ago [43]. No published data referring to $\mathrm{Br}, \mathrm{Fe}$, and $\mathrm{Sr}$ concentrations as well as of the $\mathrm{Zn} / \mathrm{Br}, \mathrm{Zn} / \mathrm{Fe}, \mathrm{Zn} / \mathrm{Rb}$, and $\mathrm{Zn} / \mathrm{Sr}$ ratios in EPF samples of patients with CP were found. In the EPF samples of cancerous prostate our results were comparable with published data for $\mathrm{Zn}$ concentrations (Table 3). The mean of $\mathrm{Rb}$ concentration obtained for EPF samples of PCa group was some lower than our data reported 38 years ago [43]. No published data referring to $\mathrm{Br}, \mathrm{Fe}$, and $\mathrm{Sr}$ concentrations as well as of the $\mathrm{Zn} / \mathrm{Br}, \mathrm{Zn} / \mathrm{Fe}, \mathrm{Zn} /$ $\mathrm{Rb}$, and $\mathrm{Zn} / \mathrm{Sr}$ ratios in EPF samples obtained from patients with PCa were found. From Table 4, it is observed that in EPF samples of PCa group the levels of $\mathrm{Rb}, \mathrm{Zn}, \mathrm{Zn} / \mathrm{Br}, \mathrm{Zn} / \mathrm{Fe}$, and $\mathrm{Zn} / \mathrm{Sr}$ are 3.2, $7.7,23.8,30.3$, and 16.1 times, respectively, lower than levels of these parameters in EPS of patients with BPH.

The range of means of $\mathrm{Zn}$ concentration reported in the literature for EPF of untreated hyperplastic prostate (from $268 \mathrm{mg} / \mathrm{L}$ to $9870 \mathrm{mg} / \mathrm{L}$ ) and cancerous prostate (from 34.7 to $722 \mathrm{mg} / \mathrm{L}$ ) varies widely (Table 3 ). This can be explained by a dependence of $\mathrm{Zn}$ content on many factors, including age, ethnicity, mass of the gland, presence of benign prostatic hyperplasia, and others. Not all these factors were strictly controlled in cited studies. Another and, in our opinion, leading cause of interobserver variability was insufficient quality control of results in these studies. In many reported papers EPF samples were dried at high temperature or acid digestion. Sample digestion is a critical step in elemental analysis and due to the risk of contamination and analytes loss contributes to the systematic uncontrolled analysis errors [51-53]. Thus, when using destructive analytical methods, it is necessary to control for the losses of TE, for complete acid digestion of the sample, and for the contaminations by TE during sample decomposition, which needs adding some chemicals. It is possible to avoid these not easy procedures using non-destructive methods. Therefore, sample-nondestructive technique like $109 \mathrm{Cd}$ radionuclideinduced EDXRF, which was developed and used by us [54-56] is good alternatives for TE determination in EPF samples.

The 109Cd radionuclide induced EDXRF developed to determine TE concentrations in prostate fluid is micro method because sample volume $20 \mu \mathrm{L}$ (one drop) is quite enough for analysis. It is another advantage of the method. Amount of human prostatic fluid collected by massage of the normal prostate is usually in range 100-500 $\mu \mathrm{L}$ [57] but in a pathological state of gland, particularly after malignant transformation, this amount may be significantly lower. Therefore, the micro method of 109Cd radionuclide induced EDXRF developed to determine TE concentrations in prostate fluid is available for using in clinical studies. Characteristically, elevated or deficient levels of TE and electrolytes observed in EPF of cancerous prostate are discussed in terms of their potential role in the initiation, promotion, or inhibition of prostate cancer. In our opinion, abnormal levels of TE contents and Zn/TE ratios in EPF of cancerous prostate could be the consequence of malignant transformation. Compared to other fluids of human body, the prostate secretion has higher levels of $\mathrm{Rb}$ and $\mathrm{Zn}$ and some other TE. These data suggest that these elements could be involved in functional features of prostate. The suppressed prostatic function can be both a cause and a consequence of BPH. However, malignant transformation is accompanied by a loss of tissue-specific functional features, which leads to a significant reduction in the contents of elements associated with functional characteristics of the human EPF (Rb and $\mathrm{Zn}$ ).

Our findings show that concentration of $\mathrm{Rb}$ and $\mathrm{Zn}$ are significantly lower in EPF of cancerous prostate as compared to their concentrations in EPF of hyperplastic prostate (Table 4). Because the concentrations of $\mathrm{Zn}$ and $\mathrm{Rb}$ on the one hand and of $\mathrm{Br}, \mathrm{Fe}$, and $\mathrm{Sr}$ on the other one in EPF changed in opposite directions during malignant transformation of prostate, such relative parameters as $\mathrm{Zn} / \mathrm{Br}, \mathrm{Zn} / \mathrm{Fe}$, and $\mathrm{Zn} / \mathrm{Sr}$ ratio may be more informative that absolute values of TE contents. Thus, it is plausible to assume that levels of some TE content and Zn/TE ratio in EPF can be used as tumor markers. However, this subject needs in additional studies.

This study has several limitations. Firstly, analytical techniques employed in this study measure only five TE $(\mathrm{Br}$, $\mathrm{Fe}, \mathrm{Rb}, \mathrm{Sr}$ and $\mathrm{Zn}$ ) concentrations in EPF. Future studies should be directed toward using other non-destructive analytical methods which will extend the list of TE investigated in EPF of hyperplastic and cancerous prostate. Secondly, the sample size of PCa group was relatively small. It had not allowed us to carry out the investigations of TE contents in PCa group using differentials like histological types of tumors, stage of disease, and dietary habits of healthy persons and patients with PCa. Despite these limitations, this study provides evidence on cancer specific $\mathrm{Rb}$, $\mathrm{Zn}, \mathrm{Zn} / \mathrm{Br}, \mathrm{Zn} / \mathrm{Fe}$, and $\mathrm{Zn} / \mathrm{Sr}$ level alteration in EPF and shows 


\section{Cancer Therapy \& Oncology International Journal}

the necessity the need to continue TE and their relationships research of EPF in prostatic diseases.

\section{Conclusion}

In this work, TE measurements were carried out in the EPF samples of hyperplastic and malignant prostate using nondestructive instrumental EDXRF micro method developed by us. It was shown that this method is an adequate analytical tool for the non-destructive determination of $\mathrm{Br}, \mathrm{Fe}, \mathrm{Rb}, \mathrm{Sr}$, and $\mathrm{Zn}$ concentration as well as for calculation of $\mathrm{Zn} / \mathrm{Br}, \mathrm{Zn} / \mathrm{Fe}, \mathrm{Zn} / \mathrm{Rb}$, and $\mathrm{Zn} / \mathrm{Sr}$ ratios in the EPF samples of human prostate. It was observed that in the EPF of cancerous prostate levels of $\mathrm{Rb}, \mathrm{Zn}$, $\mathrm{Zn} / \mathrm{Br}, \mathrm{Zn} / \mathrm{Fe}$, and $\mathrm{Zn} / \mathrm{Sr}$ significantly lower in a comparison with those in the EPF of hyperplastic prostate. In our opinion, the decrease in levels of $\mathrm{Rb}, \mathrm{Zn}, \mathrm{Zn} / \mathrm{Br}, \mathrm{Zn} / \mathrm{Fe}$, and $\mathrm{Zn} / \mathrm{Sr}$ in the EPF of cancerous prostate might demonstrate an involvement of these TE in etiology and pathogenesis of malignant prostate tumors. It was supposed that the changes of $\mathrm{Rb}, \mathrm{Zn}, \mathrm{Zn} / \mathrm{Br}, \mathrm{Zn} / \mathrm{Fe}$, and $\mathrm{Zn} /$ Sr levels in the EPF samples can be used as tumor markers in distinguishing between BPH and PCa.

\section{Acknowledgment}

The authors are extremely grateful to Dr Tatyana Sviridova, Medical Radiological Research Center, Obninsk for supplying EPF samples.

\section{References}

1. Rebbeck TR, Haas GP (2014) Temporal trends and racial disparities in global prostate cancer prevalence. Can J Urol 21(5): 7496-7506.

2. Taitt HE (2018) Global trends and prostate cancer: A review of incidence, detection, and mortality as influenced by race, ethnicity, and geographic location. Am J Mens Health 12(6): 1807-1823.

3. Siegel RL, Miller KD, Jemal A (2017) Cancer Statistics, 2017. CA Cancer J Clin 67(1): 7-30.

4. Qi D, Wu C, Liu F, Gu K, Shi Z, et al. (2015) Trends of prostate cancer incidence and mortality in Shanghai, China from 1973 to 2009. Prostate 75(14): 1662-1668

5. Carter HB, Coffey DS (1990) The prostate: an increasing medical problem. Prostate 16(1): 39-48.

6. Foo KT (2017) Pathophysiology of clinical benign prostatic hyperplasia. AJUR 4(3): 152-157.

7. Burnett AL, Wein AJ (2006) Benign prostatic hyperplasia in primary care: what you need to know. J Urol 175: S19-S24.

8. Gong EM, Gerber GS (2004) Saw palmetto and benign prostatic hyperplasia. Am J Chin Med 32(3): 331-338.

9. Lee KL, Peehl DM (2004) Molecular and cellular pathogenesis of benign prostatic hyperplasia. J Urol 172(5): 1784-1791.

10. Li W, Wu C-L, Febbo PG, Olumi AF (2007) Stromally expressed c-jun regulates proliferation of prostate epithelial cells. Am J Pathol 171(4) 1189-1198.

11. Alcaraz A, Hammerer P, Tubaro A, Schröder FH, Castro R (2009) Is there evidence of a relationship between benign prostatic hyperplasia and prostate cancer? Findings of a literature review. Eur Urol 55(4): 864-873.
12. Dai X, Fang X, Ma Y, Xianyu J (2016) Benign prostatic hyperplasia and the risk of prostate cancer and bladder cancer. A meta-analysis of observational studies. Medicine (Baltimore) 95(18): e3493.

13. Guess HA (2001) Benign Prostatic Hyperplasia and Prostate Cancer Epidemiol Rev 23(1): 152-158.

14. Aslam R, Neubauer S (2013) Dairy foods, milk, calcium, and risk of prostate cancer. Oncol Nutr Connect 21(1): 3-10.

15. Zaichick V, Zaichick S (2015) Dietary intake of minerals and prostate cancer: insights into problem based on the chemical element contents in the prostate gland. J Aging Res Clin Practice 4(3): 164-171.

16. Zaichick V, Zaichick S, Wynchank S (2016) Intracellular zinc excess as one of the main factors in the etiology of prostate cancer. J Anal Oncol 5(3): 124-131.

17. Zaichick V, Zaichick S, Rossmann M (2016) Intracellular calcium excess as one of the main factors in the etiology of prostate cancer. AIMS Molecular Science 3(4): 635-647.

18. Tavani A, Longoni E, Bosetti C, Maso LD, Polesel J, et al. (2006) Intake of selected micronutrients and the risk of surgically treated benign prostatic hyperplasia: a case-control study from Italy. Eur Urol 50(3): 549-554.

19. Zaichick V (2006) Medical elementology as a new scientific discipline. J Radioanal Nucl Chem 269(2): 303-309.

20. Ektessabi A, Shikine S, Kitamura N, Rokkum M, Johansson C (2001) Distribution and chemical states of iron and chromium released from orthopedic implants into human tissues. X-Ray Spectrom 30(1): 44-48.

21. Isaacs JT (1983) Prostatic structure and function in relation to the etiology of prostatic cancer. Prostate 4(4): 351-366.

22. Zaichick V, Zaichick S (1999) Role of zinc in prostate cancerogenesis. In: Anke M, et al. (Editors). Mengen und Spurenelemente, 19 Arbeitstagung. Friedrich-Schiller-Universität, Jena, pp. 104-115.

23. Zaichick V (2004) INAA and EDXRF applications in the age dynamics assessment of $\mathrm{Zn}$ content and distribution in the normal human prostate. J Radioanal Nucl Chem 262(1): 229-234.

24. Bornhorst J, Kipp AP, Haase H, Meyer S, Schwerdtle T (2018) The crux of inept biomarkers for risks and benefits of trace elements. Trends Anal Chem 104: 183-190.

25. Zaichick S, Zaichick V (2011) The Br, Fe, Rb, Sr, and Zn content and interrelation in intact and morphologic normal prostate tissue of adult men investigated by energy dispersive X-ray fluorescent analysis. X-Ray Spectrom 40(6): 464-469.

26. Zaichick S, Zaichick V (2011) INAA application in the age dynamics assessment of $\mathrm{Br}, \mathrm{Ca}, \mathrm{Cl}, \mathrm{K}, \mathrm{Mg}, \mathrm{Mn}$, and $\mathrm{Na}$ content in the normal human prostate. J Radioanal Nucl Chem 288(1): 197-202.

27. Zaichick V, Nosenko S, Moskvina I (2012) The effect of age on 12 chemical element contents in intact prostate of adult men investigated by inductively coupled plasma atomic emission spectrometry. Biol Trace Elem Res 147(1-3): 49-58.

28. Zaichick V, Zaichick S (2014) Age-related histological and zinc content changes in adult nonhyperplastic prostate glands. Age 36(1): 167-181.

29. Zaichick S, Zaichick V (2011) The effect of age on $\mathrm{Ag}, \mathrm{Co}, \mathrm{Cr}, \mathrm{Fe}, \mathrm{Hg}, \mathrm{Sb}$, Sc, Se, and $\mathrm{Zn}$ contents in intact human prostate investigated by neutron activation analysis. Appl Radiat Isot 69(6): 827-833.

30. Zaichick V, Zaichick S (2013) The effect of age on $\mathrm{Br}, \mathrm{Ca}, \mathrm{Cl}, \mathrm{K}, \mathrm{Mg}$, $\mathrm{Mn}$, and $\mathrm{Na}$ mass fraction in pediatric and young adult prostate glands investigated by neutron activation analysis. Appl Radiat Isot 82: 145151. 


\section{Cancer Therapy \& Oncology International Journal}

31. Zaichick V, Zaichick S (2013) INAA application in the assessment of Ag, $\mathrm{Co}, \mathrm{Cr}, \mathrm{Fe}, \mathrm{Hg}, \mathrm{Rb}, \mathrm{Sb}, \mathrm{Sc}, \mathrm{Se}$, and $\mathrm{Zn}$ mass fraction in pediatric and young adult prostate glands. J Radioanal Nucl Chem 298(3): 1559-1566.

32. Zaichick V, Zaichick S (2013) NAA-SLR and ICP-AES Application in the assessment of mass fraction of 19 chemical elements in pediatric and young adult prostate glands. Biol Trace Elem Res 156(1): 357-366

33. Zaichick V, Zaichick S (2013) Use of neutron activation analysis and inductively coupled plasma mass spectrometry for the determination of trace elements in pediatric and young adult prostate. American Journa of Analytical Chemistry 4(12): 696-706.

34. Zaichick V, Zaichick S (2014) INAA application in the assessment of chemical element mass fractions in adult and geriatric prostate glands. Appl Radiat Isot 90: 62-73

35. Zaichick V, Zaichick S (2014) Determination of trace elements in adults and geriatric prostate combining neutron activation with inductively coupled plasma atomic emission spectrometry. Open Journal of Biochemistry 1(2): 16-33.

36. Zaichick V, Zaichick S (2014) Use of INAA and ICP-MS for the assessment of trace element mass fractions in adult and geriatric prostate. Radioanal Nucl Chem 301(2): 383-397.

37. Zaichick V (2015) The variation with age of 67 macro- and microelement contents in nonhyperplastic prostate glands of adult and elderly males investigated by nuclear analytical and related methods. Biol Trace Elem Res 168(1): 44-60.

38. Zaichick V, Zaichick S (2014) Androgen-dependent chemical elements of prostate gland. Andrology \& Gynecology: Current Research 2(2) $1-15$.

39. Zaichick V, Zaichick S (2015) Differences and relationships between morphometric parameters and zinc content in nonhyperplastic and hyperplastic prostate glands. BJMMR 8(8): 692-706.

40. Zaichick V (2014) The prostatic urethra as a Venturi effect urine-jet pump to drain prostatic fluid. Med Hypotheses 83(1): 65-68.

41. Mackenzie AR, Hall T, Whitmore WFJr (1962) Zinc content of expressed human prostate fluid. Nature (London) 193(4810): 72-73.

42. Marmar JL, Katz S, Praiss DE, DeBenedictis TJ (1980) Values for zinc in whole semen, fraction of split ejaculate and expressed prostatic fluid. Urology 16(5): 478-480.

43. Zaichick V, Tsyb A, Dunchik VN, Sviridova TV (1981) Method for diagnostics of prostate diseases. Certificate of invention No 997281 (30.03.1981), Moscow, Russia

44. Zaichick V, Sviridova T, Zaichick S (1996) Zinc concentration in human prostatic fluid: normal, chronic prostatitis, adenoma, and cancer. Int Urol Nephrol 28(5): 687-694.
45. Zaichick V (1995) Applications of synthetic reference materials in the medical Radiological Research Centre. Fresenius J Anal Chem 352(12): $219-223$

46. Romics I, Bach D (1991) Zn, Ca and Na levels in the prostatic secretion of patients with prostatic adenoma. Int Urol Nephrol 23(1): 45-49.

47. Gómes Y, Arocha F, Espinoza F, Fernandez D, Vásquez A, et al. (2007) Niveles de zinc en líquido prostático de pacientes con patologías de próstata. Invest Clin 48(3): 287-294.

48. Zaichick V, Sviridova T, Zaichick S (1997) Zinc in human prostate gland: normal, hyperplastic and cancerous. Int Urol Nephrol 29(5): 565-574.

49. Kavanagh JP, Darby C (1982) The interrelationships between acid phosphatase, aminopeptidase, diamine oxidase, citric acid, $\beta$-glucuronidase, $\mathrm{pH}$ and zinc in human prostate fluid. Int J Androl 5(5): 503-512.

50. Huggins C, Scott W, Heinen JH (1942) Chemical composition of human semen and of the secretion of the prostate and seminal vesicles. Amer J Physiol 136(3): 467-473.

51. Zaichick V (1997) Sampling, sample storage and preparation of biomaterials for INAA in clinical medicine, occupational and environmental health. In: Harmonization of Health-Related Environmental Measurements Using Nuclear and Isotopic Techniques. IAEA, Vienna, pp. 123 133.

52. Zaichick V, Zaichick S (1997) A search for losses of chemical elements during freeze-drying of biological materials. J Radioanal Nucl Chem 218(2): 249-253.

53. Zaichick V (2004) Losses of chemical elements in biological samples under the dry aching process. Trace Elements in Medicine 5(3): 17-22.

54. Zaichick S, Zaichick V (2010) Method and portable facility for energy-dispersive X-ray fluorescent analysis of zinc content in needle-biopsy specimens of prostate. X-Ray Spectrom 39: 83-89.

55. Zaichick S, Zaichick V (2011) The Br, Fe, Rb, Sr, and Zn content and interrelation in intact and morphologic normal prostate tissue of adult men investigated by energy dispersive X-ray fluorescent analysis. X-Ray Spectrometry 40(6): 464-469.

56. Zaichick V, Zaichick S, Davydov G (2016) Method and portable facility for measurement of trace element concentration in prostate fluid samples using radionuclide-induced energy-dispersive X-ray fluorescent analysis. Nucl Sci Tech 27(6): 1-8

57. Moore RA, Miller ML, Mc Lellan A (1941) The chemical composition of prostatic secretion in relation to benign hypertrophy of the prostate. J Urol 46: 132-137.

\section{Your next submission with Juniper Publishers will reach you the below assets}

- Quality Editorial service

- Swift Peer Review

- Reprints availability

- E-prints Service

- Manuscript Podcast for convenient understanding

- Global attainment for your research

- Manuscript accessibility in different formats

(Pdf, E-pub, Full Text, Audio)

- Unceasing customer service

Track the below URL for one-step submission https://juniperpublishers.com/online-submission.php 